\title{
Human Rights Thinking and the Laws of War
}

David Luban

Georgetown University Law Center, luband@law.georgetown.edu

This paper can be downloaded free of charge from:

https://scholarship.law.georgetown.edu/facpub/1474

http://ssrn.com/abstract=2589082

Theoretical Boundaries of Armed Conflicts \& Hum. Rts. (forthcoming)

This open-access article is brought to you by the Georgetown Law Library. Posted with permission of the author. Follow this and additional works at: https://scholarship.law.georgetown.edu/facpub

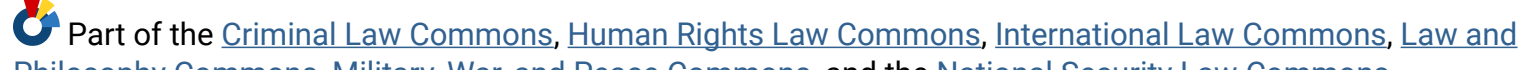
Philosophy Commons, Military, War, and Peace Commons, and the National Security Law Commons 


\title{
Human Rights Thinking and the Laws of War
}

\author{
David Luban $^{*}$ \\ [forthcoming in THEORETICAL BOUNDARIES OF ARMED CONFLICTS AND HuMAN Rights, \\ Jens Ohlin, ed. Draft of December 2, 2014. Not for quotation.]
}

In a significant early case, the ICTY found a Croatian military commander named Anto Furundzija guilty as an aider and abettor of rapes committed by his troops. In the course of its judgment, the Trial Chamber of the ICTY commented:

The essence of the whole corpus of international humanitarian law as well as human rights law lies in the protection of the human dignity of every person.... The general principle of respect for human dignity is . . the very raison d'être of international humanitarian law and human rights law; indeed in modern times it has become of such paramount importance as to permeate the whole body of international law. ${ }^{1}$

Is it true that international humanitarian law and international human rights law share the same "essence," and that essence is the general principle of respect for human dignity? Is it true that, in the words of Charles Beitz, humanitarian law is "perhaps better described as the law of "human rights in armed conflicts"'? ${ }^{2}$ To answer yes, I will argue, amounts to

\footnotetext{
* University Professor in Law and Philosophy, Georgetown University Law Center; Class of 1984 Distinguished Visitor in Ethics, Stockdale Center for Ethical Leadership, United States Naval Academy. This paper owes an obvious debt to Theodore Meron, The Humanization of Humanitarian Law, 94 AJIL 239 (2000) and Gabriella Blum, The Individualization of War: From War to Policing in the Regulation of Armed Conflicts, in Austin Sarat et al. eds., Law and War 48 (2014), available on SSRN at http://ssrn.com/abstract=2231168. The argument and analysis are, however, different from both Meron and Blum. I would like to thank Blum and Marty Lederman for comments on an earlier draft.

${ }^{1}$ Prosecutor v. Furundzija, Judgment, Case No. IT-95-17/1-T, T.Ch. II, 10 December 1998, II 183.

${ }^{2}$ Charles R. Beitz, The Idea of Human Rights 14 (2009)(quoting Sean MacBride, as quoted in Geoffrey Best, Justice, International Relations and Human Rights, 71 Int'l Affairs (1995), at 780).
} 
a reinterpretation of IHL that drifts far from its history. In its origins, IHL was not designed to protect human dignity, but to reduce human suffering. The ICTY Trial Chamber instead viewed IHL through a human rights lens that assimilates the two motivations, as does Beitz and the authors he quotes.

This is not a criticism of the Furundzija dictum. Law changes. In every field of law, latter-day authorities - paradigmatically, but not solely, courts and tribunals retroactively reinterpret the law. Their reinterpretation takes on a self-fulfilling, performative role: the court's saying it is so helps make it so. This is the path of the law; it is one way law evolves. Perhaps the nature of IHL has evolved over time in the direction of human rights thinking, and should evolve that way.

That, in fact, is the view I will defend - with some qualifications - in the final sections of this essay. First, though, I want to explore the very different genealogies of IHL and human rights law, and explain how human rights thinking migrated into IHL. (To briefly foreshadow my argument, I attribute the migration to international criminal law, military occupations, and the U.S. war on terrorism.) In the final sections, I explore two ways human rights thinking can be pursued in wars. One of them, I will argue, overplays and overestimates what human rights thinking can accomplish. It does so by, in effect, willing away fundamental differences between war and peace. The other is an approach that I have defended for more than three decades. It consists, at bottom, of taking a civilian's-eye view of the disasters of war and reading the law accordingly recognizing, one might say, that Mother Courage and her children matter just as much to the law of war as Henry V and his band of brothers.

\section{Human rights thinking and human dignity}


Human rights law gives pride of place to what Furundzija calls "the general principle of respect for human dignity." Most of the central international human rights instruments, including the UN Charter, the UDHR, the two major human rights covenants, the Helsinki Accords, the African Charter of Human and Peoples' Rights, the American Convention on Human Rights, and the European Charter of Human Rights, link human rights with human dignity. Some of these documents declare that human dignity is the basis of human rights.

Does that make human dignity the "essence" of human rights law, as the Furundzija dictum says? Set to one side the question of whether human rights law has an essence, an issue about which philosophers disagree. ${ }^{3}$ Set aside as well the question of what human dignity is, exactly - for of course the concept of human dignity lacks anything remotely like a consensus definition. A worked-out theory of human rights would have to answer these questions. Here I am asking something different: whether, pre-theoretically and intuitively, there is a connection between human dignity and human rights. I think the answer is yes.

Whatever one's theory of human rights, ascribing moral importance to them involves at least two fundamental commitments: that every individual human being should count as a worthy object of concern, and that no one should have to beg for their rights. Rights-fulfillment is not charity on the part of the powerful toward the less fortunate. The former commitment is a commitment to human dignity, at the very least because viewing individuals as worthy objects of concern confers dignity on them. The

\footnotetext{
${ }^{3}$ This is one of the major themes of Beitz's book, supra note 2. See also John Tasioulas, Human Rights, Universality and the Values of Personhood: Retracing Griffin's Steps, 10 European J. Phil. 79, 88-94 (2002). Compare Beitz's anti-essentialist view with James Griffin, On Human Rights (2008)(arguing that human rights are protections of human beings' normative agency).
} 
latter is a commitment to treat human rights as rights. It is hard to see how someone who rejects the commitment to valuing humans as individuals could believe in human dignity under any conceivable definition. Nor could someone who rejects the commitment to viewing concern for the individual as an entitlement rather than a gratuity believe that human rights are, in fact, rights. Someone who shares these individual-value and entitlement commitments will engage in what I call human rights thinking, and will incline to bring it into the interpretation of law, including humanitarian law. Notice also that these commitments imply the kind of universalism characteristic of international human rights: everyone has human dignity and human rights, regardless of nationality.

Let me reiterate that human rights thinking is not the same thing as human rights theory or human rights law. The individual-value and entitlement commitments are pretheoretical and pre-legal. As bare normative attitudes, they are too general and too thin to generate a theory of human dignity or human rights on their own. A full-fledged theory will need additional premises to get off the ground.

To illustrate: some religious people will ground human dignity in the divine creation of an immortal human soul, or in humanity's divinely-ordained superiority to the rest of nature. Secularists might ground human dignity in rationality, or in autonomy, or in agency - or, as I think, in the reciprocal recognition of the dignity of others: the relation between the dignifier and the dignified. ${ }^{4}$ Provided the believer and the secularist share a commitment to honoring individual human worth as an entitlement, both engage in human rights thinking, and both may wind up approaching concrete practical issues of implementation the same way even though their theories of human dignity are radically inconsistent.

\footnotetext{
${ }^{4}$ David Luban, Torture, Power, and Law 141-42 (2014).
} 
What about the entitlement commitment? As Joel Feinberg explains, Rights are not mere gifts or favors, motivated by love or pity, for which gratitude is the sole fitting response. A right is something that can be demanded or insisted upon without embarrassment or shame....A world with claim-rights is one in which all persons, as actual or potential claimants, are dignified objects of respect, both in their own eyes and in the view of others. ${ }^{5}$

If Feinberg is right (as I think he is), the entitlement commitment seamlessly meshes with the commitment to viewing others as, in his words, dignified objects of respect. But that commitment could come from many possible religious or secular doctrines - or, for that matter, from no doctrine at all.

\section{Human rights thinking and humanitarianism: no necessary connection}

The next question is whether everyone who participates in the project of furthering humanitarian law shares the twin commitments of human rights thinking. The answer is no; they may, but they don't have to. An anti-individualist who believes that individuals take on value only within and through collectivities, or even a cynic who doesn't think individuals matter much in the great scheme of things, can still favor regulating war to minimize suffering and destruction; and a commitment to eliminate unnecessary suffering and destruction does not imply that humane treatment is a right.

I don't mean this purely as a theoretician's point. Everyone working in this area has met tough-minded humanitarians with years of field experience who are allergic to human rights pieties and skeptical that their job has to do with enhancing human dignity rather than stanching the flow of blood in catastrophes. Some of these workers nonetheless put their lives on the line repeatedly in the world's most dangerous conflict

\footnotetext{
${ }^{5}$ Joel Feinberg, Social Philosophy 58-59 (1973).
} 
zones, perhaps feeling more affinity with the combat soldiers than with the human rights NGOs. For that matter, operational military lawyers and advisors may be whole-heartedly committed to humanitarian law, but view it as a matter of military honor rather than human rights. Of course, other humanitarian workers and lawyers do share the individualvalue and entitlement commitments, and believe that their humanitarian efforts are part of a larger human rights project. As a factual matter, then, human rights thinking is optional, not mandatory, for humanitarians. There is no intrinsic connection between the humanitarian project and the human rights project.

As the papers in this volume illustrate, it is a difficult and contested legal question whether international human rights law (hereafter "IHRL") takes priority over IHL, or the other way around, or neither, in armed conflicts. This can be treated as a lawyer's technical question. As such, it quickly leads down the rabbit hole into a Wonderland of dueling dicta, fragmented legal authorities, conflicting proportionality tests, and numbing intricacy. The International Court of Justice and the UN Human Rights Committee tell us that human rights law applies at all times, but they add that in wartime it must be interpreted through the lex specialis of IHL. ${ }^{6}$ The European Court of Human Rights finds that the European Charter does not apply in active combat when NATO is bombing a Belgrade television station, but it does apply when Turkish troops cross the border and murder shepherds in Iraq. ${ }^{7}$ The U.S. government and the UN Human Rights Committee offer conflicting interpretations of the grammatically ambiguous jurisdiction clause in the ICCPR, with one finding human rights obligations only within a state's own territory and

\footnotetext{
${ }^{6}$ ICJ Nuclear Weapons Advisory Opinion; Human Rights Committee General Comment 31, §11.

${ }^{7}$ Banković, Issa.
} 
jurisdiction while the other finds them everywhere - both readings that the clause can support. $^{8}$ And so on.

But the legalisms are pretty clearly a stand-in for a broader debate about the very nature of war and peace and the laws that regulate them, and that debate is not technical at all. Is IHRL fundamentally law for peacetime, because it assumes a set of peacetime institutions to give it effect? Must it, therefore, give way in armed conflicts to the law of war? Or is IHRL a universal law governing war as well as peace? How we answer that question will very likely turn on whether we share the commitments of human rights thinking. Whatever one's answer to legal questions about the scope and meaning of treaties, the current state of customary international law, or the doctrine of lex specialis, texts like the Furundzija dictum vividly illustrate something far less legalistic: human rights thinking at work in IHL. Even if the legal authorities are ambiguous and opaque, yielding no obvious answer to questions about the reach of human rights law during armed conflict, the urge to export human rights thinking to IHL is evident, and in some cases it affects legal outcomes. ${ }^{9}$

\section{A Genealogy of Humanitarian Law}

To understand how far human rights thinking departs from the original spirit of IHL, we would do well to revisit the "creation myths" of IHL and IHRL. As every student of the subject knows, modern IHL began when the Swiss businessman Henri Dunant visited the battlefield of Solferino shortly after the battle; the horrible suffering of

\footnotetext{
${ }^{8}$ General Comment $31, \S \S 3,10$.

${ }^{9}$ This phenomenon might be regarded as an instance of the emergence of "humanity law," Ruti Teitel's term for a kind of unified-field theory of protections of human interests running across IHL, IHRL, and ICL. Ruti Teitel, Humanity's Law (2011). I think of human rights thinking as a more discrete and particular phenomenon; and in any case, as I show below, "humanity" is ambiguous. It can be interpreted in an aggregative way that excludes human rights thinking from IHL, or in the individuating, human dignity oriented, way of the individual-worth and entitlement commitments. See the discussion below of the genealogy of humanitarian law.
} 
thousands of wounded and dying men moaning for surcease moved Dunant to found the

Red Cross. The Red Cross's purpose was relief of suffering in the horrors of war, and that was the motivation for the founding treaties of modern IHL. In philosophical terms, we could say that IHL was Benthamite in spirit - although I will use the lower-case "benthamite" to decouple the point I am making from the historical Bentham. A benthamite focuses on aggregate pleasure and pain as the measure of good and bad, and its moral imperatives are to maximize pleasure and minimize pain. ${ }^{10}$ Philosophers refer to the pain-minimization component as "negative utilitarianism," and humanitarianism in war is plainly a form of negative benthamism. ${ }^{11}$

Notoriously, utilitarianism in both its negative benthamite form (focusing on painminimization) and other forms is an anti-individualist doctrine. What matters is the aggregate of utility within some population of sentient beings. In the words of H.L.A.

Hart,

utilitarianism is not, as it is sometimes said to be, an individualistic and egalitarian doctrine, although in a sense it treats people as equals, or of equal

\footnotetext{
${ }^{10}$ So much, at any rate, corresponds with the thought of the historical Bentham, as the opening paragraphs of The Principles of Morals and Legislation makes clear.

${ }^{11}$ John Fabian Witt argues that in the $19^{\text {th }}$ century there was also an alternative conceptualization of wartime suffering as an ennobling byproduct of the hard work of accomplishing just ends in the world. Witt, Two Conceptions of Suffering in War, in Knowing the Suffering of Others 129 (Austin Sarat ed., 2014). Such a view, which Witt finds in the outlook of Dunant's contemporary Francis Lieber, -- the drafter of the first modern code of IHL - of course has a hard time making sense of the suffering of innocent civilians. Indeed, Lieber's thinking is quite antithetical to negative benthamism, and thus to the tradition of IHL I am describing. Famously, Lieber was among those who believed that ferocious wars that inflict a great deal of suffering will be shorter, and therefore save more lives in the long run. As Witt shows in his magnificent historical study Lincoln's Code: The Laws of War in American History (2012), U.S. delegates to the Hague conferences trotted out Lieber's "short, sharp wars" thesis to ward off humanitarian rules they disliked. Id. at . Thus, the tradition of IHL I am describing is not at all Lieber's view; however, it does represent the international view embodied in the St. Petersburg Declaration and the Hague Conventions.

Of course, what is remarkable about Lieber's "short, sharp wars" thesis is its total lack of any empirical basis. Obviously, there is no way to know whether more or fewer lives would have been lost if a war had been fought differently under different rules. There is nothing "realist" about an argument couched in the idiom of alternate-reality fiction.
} 
worth. For it does this only by in effect treating individual persons as of no worth; since not persons ... but the experiences of pleasure or satisfaction or happiness which persons have are the sole items of worth or elements of value. ${ }^{12}$

Each counts for one because none counts for anything. In the familiar language of Rawls, Nozick, and Hart, utilitarianism disregards the separateness of persons.

Within humanitarian law, there is no clearer example than the doctrine of in bello proportionality, which forbids attacks in which "incidental" civilian damage is anticipated to exceed concrete and direct military advantage. The "incidental" civilian damage is aggregate damage from the attack. It follows that individual civilians can lose protection from attack merely because they have the bad luck to be near an important target and surrounded by too few other civilians. Their human rights play no role in the proportionality assessment, which aggregates damage to civilian persons, and indeed aggregates damage to persons with damage to inanimate objects. Perhaps the decision to label unintended civilian damage "incidental" is already a tip-off that human dignity does not play a starring role in the proportionality rule.

One might object that the proportionality rule is simply one feature of the broader principle of distinction, and that principle should be understood as a recognition of the human dignity of non-combatants. That is possible, and understanding it this way represents human rights thinking in IHL. But the principle of distinction can just as readily be interpreted along benthamite lines as an effort to minimize unnecessary suffering in war, given the axiom that targeting civilians is militarily unnecessary.

${ }^{12}$ H. L. A. Hart, Between Utility and Rights, 79 Columb. L. Rev. 828, 830 (1979). 
That is exactly how the founding documents of IHL reasoned. Consider the preamble to the 1868 St. Petersburg Declaration, one of the earliest documents in modern IHL:

Considering that the progress of civilization should have the effect of alleviating as much as possible the calamities of war:

That the only legitimate object which States should endeavour to accomplish during war is to weaken the military forces of the enemy;

That for this purpose it is sufficient to disable the greatest possible number of men....

The first clause sets out a benthamite rationale for IHL (alleviating the calamities of war), while the third asserts the (debatable but henceforth axiomatic) military proposition that disabling combatants is by itself sufficient to win wars. Although the operative portions of the St. Petersburg Declaration do not include the principle of distinction, the principle follows naturally from the reasoning in this preamble. If disabling combatants suffices to win wars, targeting civilians is unnecessary, so it is not (in the words of the second clause) a "legitimate object" for states. The reasoning, grounding IHL in the benthamite concern to alleviate the calamities of war rather than respect for human dignity, seems the more plausible origin of the principle of distinction.

This is not to deny that there were human dignity concepts in the historical law of war. Quite the contrary: from the time of The Iliad to the chivalric period to modern times, the laws of war placed heavy emphasis on the dignity of the warriors. When two Homeric princes set about the grim business of trying to slaughter each other, recognizing

\footnotetext{
${ }^{13}$ Declaration of St. Petersburg, Nov. 29, 1868, available at http://avalon.law.yale.edu/19th_century/decpeter.asp.
} 
the enemy as a doughty warrior like oneself is the form respecting human dignity takes.

In the Mahabharata, the dharmayudda ("righteous war") emphasizes chivalry and symmetrical response: chariots must fight other chariots, and it would be dishonorable, contrary to the dharma, for a charioteer to fight a mere foot-soldier. ${ }^{14}$ Parallel examples of dignity understood as warrior's honor can be found in texts as disparate as Chinese chronicles of the Duke of Sung and the medieval English poem The Battle of Maldon, both of which portray commanders for whom losing honorably is better than winning dishonorably. ${ }^{15}$ Warriors' honor was and remains the central concept of military ethics as militaries understand it. The dignity of the warrior may be the prototypical conception of human dignity in warfare. Warriors had agency; civilians would be treated mercifully as a matter of policy or compassion, but that would be the warrior's prerogative, a matter of warrior's virtue and not of the dignity and rights of civilians.

To be sure, the Martens Clause of the 1899 Hague Convention places civilians under the protection of the "laws of humanity, and the requirements of public conscience." But it never specifies the content of those laws or explains what public conscience requires. The preamble speaks of a "desire to diminish the evils of war so far as military necessities permit," but this is just as consistent with negative benthamism as it is with human rights thinking. Historical evidence suggests that the drafters had in mind the persecution of Christians in the Ottoman Empire, which were denounced as offenses

\footnotetext{
${ }^{14}$ In recent times, an Indian general blamed the dharmayudda tradition for the bad decision to deploy Indian tanks solely against enemy tanks in the 1965 India-Pakistan war. Kaushik Roy, Hinduism and the Ethics of Warfare in South Asia: From Antiquity to the Present (CUP, 2012), p. 245.

${ }^{15} 5$ The Chinese Classics 183 (James Legge ed. and trans., 1893), quoted in Michael Walzer, Just and Unjust Wars: A Moral Argument with Historical Illustrations 225 (1978). The Battle of Maldon (Douglas B. Killings trans. 1991), at http://www.english.ox.ac.uk/oecoursepack/maldon_resources/Translations/Killingsfull.htm.
} 
against the laws of humanity. ${ }^{16}$ We could call this human rights thinking; if so, however, the emphasis is on the collective right of a religious minority, and not individual human rights more generally. The only place civilian rights are mentioned as such in the Hague Convention is in article 46 of the Annex to Hague II. Article 46 protects "[f]amily honor and rights, individual lives and private property, as well as religious convictions and liberty," but only in the context of military occupation - a point that we shall see is extremely important in modern debates about IHL and human rights law. 17 "Family honor and rights" refers obliquely to the rights of families not to have their wives and daughters raped; the individual right of the wives and daughters not to be raped is subsumed into family honor. So, while the Martens Clause and article 46 can be regarded as proto-human rights doctrines for countries under military occupation, both are limited in scope and radically defective by modern standards. And neither so much as mentions individual human rights as a moral or legal category.

\section{Humanitarianism and disaster relief}

Sometimes newcomers find the label "humanitarian law" applied to the law of armed conflict startling - almost a joke, and not an especially funny one. War is the least humanitarian of activities. The incongruity dissolves, of course, once we understand that the label doesn't refer to war-fighting, but to the effort to mitigate the suffering it inflicts.

In this respect, humanitarianism in the face of war is like humanitarianism in the face of earthquakes, floods, plagues, or famines: it aims at disaster relief. When the

\footnotetext{
${ }^{16}$ On this point see the fascinating article by Peter Holquist, "Crimes Against Humanity": Genealogy of a Concept (unpublished manuscript 2012), at 15-16. Holquist traces the concept back to the energetic activism of progressive Russian jurists in czarist Russia. For a skeptical reading of the Martens Clause, see Antonio Cassese, The Martens Clause: Half a Loaf or Simply Pie in the Sky?, 11 Eur. J. Intl. L. 187 (2000). Cassese argued that the great powers inserted the Martens Clause in order to forestall more specific protections of occupied countries favored by smaller states.

${ }^{17}$ Article 46, Annex.
} 
disasters are natural, we do not think of the victims' sufferings as human rights violations. Mother Nature has not violated the victims' human rights by causing an earthquake. ${ }^{18}$

From the point of view of common people through most of history, wars were like natural disasters. The Second Horseman of the Apocalypse, "given power to take peace from the earth and to make men slay each other" (Revelations 6:3-4), rides side by side with Famine, Pestilence, and Death, representing natural disasters. ${ }^{19}$ Wars were launched by distant princes for inscrutable reasons; warriors descended on the countryside like a force of nature; common people suffered and died, as in a plague. Those were the facts of life. The humanitarian mission, when it existed, was to ease the pain - not because the rights of the suffering had been violated, but because human compassion and simple decency demanded it.

Of course, we don't have to see things this way: we can recognize that warfighters are not impersonal violent forces; they have agency and responsibility. International criminal law insists that we view them that way - and, I will suggest below, international criminal law was one of the forces that brought human rights thinking into humanitarian law. My point here is that in its original motivation, humanitarian law is more like disaster relief than the vindication of rights.

Disaster relief seldom if ever makes the victims of a large-scale disaster whole; that is nearly impossible. This is another signal that humanitarianism has little to do with the rights of the victims. There is an illuminating parallel in the law of torts. When an

\footnotetext{
${ }^{18}$ This is not to deny that states may violate their human rights ex ante by neglecting earthquake-safety measures and ex post by doing too little to respond to the catastrophe.

${ }^{19}$ Today, thanks to Amartya Sen, we know that famines are generally man-made disasters, not natural disasters. Sen, Poverty and Famines: An Essay on Entitlement and Deprivation (1983)(arguing that famines result from lack of money, not lack of food). It would be anachronistic to think the authors of the Book of Revelations held this view.
} 
individual suffers a tort, she has a right to compensation, typically if fancifully described as "making her whole." In mass torts with thousands of victims, make-whole compensation seldom happens; it would cost too much, and the threat of defendant bankruptcy that would further deplete the settlement fund keeps awards relatively small. The settlement fund pays victims a few cents on the dollar; it offers help but not full compensation. As thoughtful commentators have noticed, that makes the settlements in mass tort more like disaster relief than make-whole compensation - and to just that extent, they have faint connection to the victims' rights, only to their needs, and even there only up to a point. ${ }^{20}$

And, of course, "disaster relief" as I have described it is another name for negative benthamism in the face of catastrophes.

\section{A Genealogy of International Human Rights Law}

The creation story of the UDHR is also well known. It has been elegantly told in the books by Mary Ann Glendon and Johannes Morsink. Only slightly less well-known is the diplomacy that went into the U.N. Charter's embrace of human rights (although on the latter issue there is historical controversy over whether the prime movers were diplomats or NGOs). ${ }^{21}$ Notable in the UDHR story are:

\footnotetext{
${ }^{20}$ John C. P. Goldberg, Misconduct, Misfortune, and Just Compensation: Weinstein on Torts, 97 Colum. L. Rev. 2034 (1997)(analyzing the thinking of Judge Jack Weinstein, one of the major figures in both the theory and practice of U.S. mass tort litigation, to show that Weinstein models mass tort settlement on disaster relief).

${ }^{21}$ Mary Ann Glendon, A World Made New: Eleanor Roosevelt and the Universal Declaration of Human Rights (2002); Johannes Morsink, The Universal Declaration of Human Rights: Origins, Drafting, and Intent (2000). On the human rights language in the Charter and the controversy surrounding it, see James Loeffler, "The Conscience of America": Human Rights, Jewish Politics, and American Foreign Policy at the 1945 United Nations San Franciso Conference, 100 J. Amer. Hist. 401 (2013) and the sources cited in that article, at 402 n. 2, 3.
} 
(i) the focus on individual rights - in which the individualist emphasis, championed by the Lebanese diplomat-philosopher Charles Malik, ultimately prevailed over Soviet objections; ${ }^{22}$

(ii) the decision to ground individual rights in "human dignity" (a phrase originally inserted in the drafts by René Cassin, to echo the UN Charter's invocation of "the dignity and worth of the human person"); and

(iii) the inclusion in the Preamble of the important claim that human beings "are endowed with reason and conscience and should act towards one another in a spirit of brotherhood." As Glendon tells the story, the latter idea was a true East-West product. When he submitted his draft of the UDHR, Cassin explained that "the concept of solidarity and fraternity among men" was one of its two leading ideas (the other was "that every human being has a right to be treated like every other human being"). ${ }^{23}$ Cassin's idea was endorsed by the influential Chinese delegate P. C. Chang, who emphasized a Confucian concept similar to Cassin's "solidarity and fraternity": "two-man mindedness" (ren, 仁, typically translated as "sympathy" or "benevolence"). ${ }^{24}$ Eventually, the drafters chose to call this capacity "conscience" - perhaps not the best word, but etymologically suggestive ('con-science', 'knowing-with', suggests two-man mindedness).

The idea was clear even if the word-choice is not: reason alone, unaccompanied by conscience, fraternity, sympathy, ren (call it what you will ) cannot motivate us to care

\footnotetext{
${ }^{22}$ Glendon, at 39-42.

${ }^{23}$ Glendon, at 67.

${ }^{24}$ Id. The Analects of Confucius offers two characterizations of ren: "Now the ren man, wishing himself to be established, sees that others are established, and, wishing himself to be successful, sees that others are successful." Analects 6:30. "When you are out in the world, act as if meeting an important guest. ... What you don't want done to yourself, don't do to others" (the so-called negative Golden Rule), Analects 12:2.
} 
about the rights of distant strangers in distant lands. ${ }^{25}$ The important point for present purposes is that benevolence and sympathy are emphatically not the moral sentiments at work in armed conflict. On the battlefield, the prevailing moral sentiments are hate, rage, fear, and one-sided loyalty, occasionally tempered with compassion. There can hardly be a clearer indication that the drafters of the UDHR were not thinking about standards of conduct in war.

Indeed, the opening paragraphs of the UDHR's preamble focus entirely on peace, arguing that human rights are the precondition of peace; and of course the UN Charter's preamble begins with the determination "to save succeeding generations from the scourge of war, which twice in our lifetime has brought untold sorrow to mankind." The contrast drawn in both documents is between a world of human rights and peace, and a world bereft of human rights, and as a consequence doomed to the untold sorrow of war. The idea of human rights as standards of conduct in war was simply not in the same conceptual universe as the Charter and the UDHR - not because of substantive disagreement, but because the Charter and the UDHR projects are to offer a roadmap out of war, not a roadmap for how war must be waged.

For the framers of human rights law, the main point was to get states to honor the human rights of their own people. Eventually, the project expanded to include the notion that the international community should provide backup for the human rights of people in other states whose own governments would not or could not honor them. The thought

\footnotetext{
${ }^{25}$ The inadequacy of reason alone is a philosophically debated proposition, but this is not the place to debate it. The debate goes back at least as far as Adam Smith, Hume, and Kant, with the latter insisting that reason alone suffices to derive and motivate human rights, while Smith and Hume believed that moral motivation comes from a faculty of sympathy that is distinct from reason.
} 
exemplified by the Furundzija dictum - that states should honor the human rights of a military adversary's people during armed conflict - was not yet on the horizon.

As further evidence consider the subsequent development of human rights doctrine into the current UN formula "respect, protect, fulfill": "By becoming parties to international treaties, States assume obligations and duties under international law to respect, to protect and to fulfill human rights. ${ }^{, 26}$ The philosophical source of this mantra is Henry Shue's powerful argument that the very structure of rights implies social guarantees that people can actually enjoy the substance of rights. ${ }^{27}$ Shue argued that social guarantees imply the three-level obligation in the formula: social guarantees include steps taken not only to avoid infringing rights, but to protect against infringement by others and to ensure to the extent possible that the rights are fulfilled and do not remain mere words on paper. ${ }^{28}$ Shue began by working on the right to adequate food; official bodies subsequently expanded his rights analysis to include, for example, the right to housing and to a livable environment - all of which, it was argued, must be respected, protected, and fulfilled by states. ${ }^{29}$

Obviously, "respect, protect, fulfill" is a thick and demanding set of obligations, far thicker than the requirement that states merely respect rights by not violating them. If

\footnotetext{
${ }^{26}$ Office of the High Commissioner for Human Rights, International Human Rights Law, available at http://www.ohchr.org/en/professionalinterest/pages/internationallaw.aspx.

${ }^{27}$ Henry Shue, Basic Rights: Subsistence, Affluence, and U.S. Foreign Policy 13 (1980).

${ }^{28}$ Id. at 52, 60. UN official Asbjørn Eide introduced the current terminology in Eide, The International Human Rights System, in Food as a Human Right 154 (Asbjørn Eide, Wenche Barth Eide, Susantha Goonatilake, Joan Gussow, and Omawale eds., 1984). Eide explicitly credits Shue with this conception of human rights (id.); Eide's duty to "respect" rights corresponds with Shue's duty "to avoid depriving" people of the rights, while his duty to "fulfill" the rights corresponds with Shue's "duty to aid" (dropping, however, Shue's argument that the duty to aid is grounded in reparation for earlier deprivation).

${ }^{29}$ On "respect, protect, fulfill" in connection with the right to food, see Committee on Economic, Social and Cultural Rights, General Comment 12, Right to adequate food (20 ${ }^{\text {th }}$ session, 1999), U.N. Doc. E/C.12/1999/5 (1999), §15. On the right to housing and a safe environment, see the African Commission on Human Rights's decision in SERAC v. Nigeria, Comm. No. 155/96 (2001), §§44-47. In SERAC the African Commission expands "respect, protect, fulfill" even further to "respect, protect, promote, fulfill."
} 
"respect, protect, fulfill" indeed represents the structure of human rights in the best thinking of the human rights community, it becomes clear that human rights is a peacetime project. A state at war can hardly be expected to provide social guarantees to fulfill a panoply of human rights for the population of its adversary. I note that Shue himself is skeptical that IHL has much to do with human rights. ${ }^{30}$

\section{The natural state of humankind}

Deeply woven into the two modes of thinking I have been describing is the question of whether war or peace represents the baseline state of human existence. Of course Hobbes placed this question at the heart of his political theory: the state of nature is the state of war; and he believed that the realm of international relations, where no sovereign reigns over states, exemplifies the state of nature. He does not deny that states are sometimes at peace. Rather, he argues that even if "there had never been any time, wherein particular men were in a condition of warre one against another; yet in all times, Kings, and Persons of Soveraign authority, ... are in continuall jealousies, and in the state and posture of Gladiators." 31 This is an ancient view. Plato, who argued that only just wars can legitimately be waged, also held that Greeks and barbarians are "enemies by nature." 32 And anthropological evidence suggests that our evolutionary ancestors, the hunter-gatherers whose way of life constitutes 99.5 per cent of homo sapiens' timeline, were extremely violent. ${ }^{33}$

\footnotetext{
${ }^{30}$ Henry Shue, Laws of War, in The Philosophy of International Law 511-16 (Samantha Besson \& John Tasioulas eds., 2010). In war, Shue remarks, "shit happens," and the best we can demand is to constrain the shit.

${ }^{31}$ Hobbes, Leviathan 90 (Richard Tuck ed., 1991).

${ }^{32}$ Plato, Republic, 470e. The argument that only just wars may legitimately be waged comes from Plato, Alcibiades I, 109d.

${ }^{33}$ Azar Gat, War in Human Civilization 11-36 (2006).
} 
Of course we know the countervailing arguments that belligerence is not the baseline condition of humankind. Our evolutionary potential for violence can be tamed, depending on social institutions and context; the violence of hunter-gatherers tells us very little about violence today. Hobbes's great critic Pufendorf pointed out that even without a sovereign, states can and do enter into friendship and alliances; so Hobbes's "inexcusable" view is "a contradiction evident to the common sense of mankind." ${ }^{34}$ For Pufendorf, "nature has established a kind of kinship among men." 35 Though admittedly "kinship usually has a rather weak force among those who live in natural liberty with each other," ${ }^{36}$ it suffices to make "common sociality" possible. ${ }^{37}$

Such debates are irresolvable, and it is not my purpose to delve into them any further. The important point is that those who see peace as the normal condition of human life will regard respect for peacetime human rights as a baseline, and the normative requirements in war as an aberration. And, of course, vice-versa: those who regard war as regrettable but not aberrational will grant equal normative rank to the laws of war, and won't be inclined to interpret them through human rights thinking. Precisely because the arguments about the natural baseline of human existence are impossible to resolve, this clash of normative commitments will be as well.

\section{The Great Transformation}

It is an interesting historical question when human rights thinking first began to enter IHL. Theodore Meron dates the "humanization of humanitarian law" to the 1968

\footnotetext{
${ }^{34}$ Samuel Pufendorf, The Law of Nature and of Nations, II.2.8.

${ }^{35}$ Pufendorf, On the Duty of Man and Citizen 64 (James Tully ed. 1991), I.8.1; also id. at 119, II.1.11.

${ }^{36}$ Id. at 119 , II.1.11.

${ }^{37}$ Id. at 64, I.8.1.
} 
Tehran conference and a pair of 1970 UN Secretary General reports. ${ }^{38}$ But we can see glimmerings already in the Geneva Conventions of 1929 and 1949. The 1929 Convention states that prisoners of war "are entitled to respect for their persons and honor" (article 3) - a dignity-based right - and then spells out the detailed obligations of captors to POWs. And common article 3 of the 1949 Conventions, prohibiting various kinds of mistreatment of captives, is clearly a mini-human rights treaty within the broader protections of the Conventions. It seems overwhelmingly likely that the 1949 Conventions were inspired by the same revulsion against the mass human rights violations of World War II that gave birth to the nearly-contemporaneous UDHR.

An even clearer example of human rights thinking in IHL is the prohibition on reprisals against civilians in Additional Protocol I to the Geneva Conventions (1977). ${ }^{39}$ For the first time, it became a rule of warfare that the traditional method of policing enemy misconduct in wartime - self-help by taking reprisals - could never include targeting civilians, even if the enemy misconduct itself targets civilians.

Conspicuously, though, the Geneva Conventions do not use the language of human rights, perhaps because in 1949 human rights law did not exist, and human rights talk seemed visionary rather than practical. By 1977 the preamble to AP I explains its goal as "protecting the victims of armed conflicts," which sounds more like rights protection than the mitigation of suffering. But even the Additional Protocols make no explicit mention of human rights as a category, and certainly there is no reference to the international human rights covenants, even though they entered into force the previous

\footnotetext{
${ }^{38}$ Meron, supra note $*$, at .

${ }^{39}$ Additional Protocol I, art. 51(6). On the point that this represents human rights thinking, see Gabriella Blum, The Fog of Victory, 24 EJIL 391, 403 (2013).
} 
year. Thus, if human rights thinking motivated the GCs and their Protocols, it did so rather furtively - it was the moral commitment that dare not speak its name.

Given their different DNA, what brought human rights thinking into humanitarian law? Almost all observers agree that visual images of dead and wounded civilians, shown in near-real time on television or spread through social media, have a great deal to do with it. What about developments within the law? Her, I suggest, three are decisively important. The first is the rebirth of international criminal law, particularly the creation of the ICTY in response to the Balkan Wars. The second is the increasing salience of the law of belligerent occupation. And the third is the U.S. war on terrorism.

International criminal law. For our purposes, the most important fact about the Balkan Wars is that what began as a war of secession - a fight by the Federal Republic of Yugoslavia to stop its components from breaking away - morphed into a war of ethnic cleansing and annihilation, in which attacks on civilian populations became, in actual fact, the dominant war aim for at least some of the contesting forces. As a result, when the Security Council created the ICTY and the modern era of international criminal law began, the crimes at the top of its agenda were attacks on civilians and civilian targets. Add to this that Yugoslavia had been at peace for 45 years, successfully managing its ethnic tensions, so the horrific ethnic violence had no fig-leaf of inevitability to it. Third, it was a European war, that is, a war in the region of the world that most firmly embraced the linkage of human rights with peace. Taken together, these facts overwhelmingly suggested that the war crimes and crimes against humanity in former Yugoslavia should be conceptualized as violations of the human rights of innocent, peaceful civilians. 
Against such a background, the human rights thinking of the Furundzija dictum comes naturally. Yugoslavia and its component regions could have remained part of the realm of rights, in which civilians would enjoy lives of human dignity as they had for decades. Instead, the conflict entrepreneurs seceded from the realm of rights and blew it to smithereens, not as a side-effect of some conceivably legitimate war aim, but as a central effort to deprive civilians of their rights. The jurisprudential focus becomes the rights of civilians.

Quite apart from the particularities of the Yugoslav tribunal, criminal law lends itself naturally to human rights thinking. Crimes with human victims are easily conceived as violations of their victims' rights, as well as of the public order. ${ }^{40}$ This changes the emphasis of IHL from prophylactically regulating the discipline of military forces - the main purpose of the GCs and their additional protocols - to vindicating victims' rights. Gabriella Blum has noted that international criminal law individualizes agency in war crimes, because it charges individual defendants, rather than holding the entire collectivity responsible for intercommunal violence - even though the latter might be a more truthful way to look at matters. ${ }^{41}$ I agree with Blum, but my present point is that ICL also individualizes victims. The indictment will charge that perpetrator $\mathrm{P}$ killed victims $\mathrm{A}, \mathrm{B}$, and $\mathrm{C}$, and raped victims $\mathrm{D}, \mathrm{E}$, and $\mathrm{F}$, and that these were grave breaches and crimes against humanity. The fatal encounter involves a rights-violator with a name

\footnotetext{
${ }^{40}$ Of course not all war crimes cause direct harm to human victims. In the Rome Statute of the ICC, causing disproportionate damage to the natural environment, transferring civilians into occupied territory, intentionally targeting historic monuments, declaring that no quarter will be given (regardless of subsequent conduct), and employing banned weapons (even if they cause no harm) are war crimes: art. 8(b)(iv), (viii), (ix), (xii), (xx). None of these directly or necessarily violates the human rights of any determinate human victim.

${ }^{41}$ Blum, The Individualization of War, at . Martti Koskenniemi makes a similar point in Between Impunity and Show Trials, 6 Max Planck Yrbk. Int'1. L. 1, 11-16 (2002)(arguing that it falsifies history to focus on individual rather than collective guilt in large-scale criminal enterprises).
} 
and the named victim whose rights are violated. Under the retributive and expressive rationales for criminal punishment (although not the deterrence or incapacitation rationales), the justice meted out by the tribunals aims to vindicate the dignity of individualized victims. This is human rights thinking, even if ICL is by no means identical with human rights law. The vindication of human dignity, not (or not only) the reduction of aggregate suffering, lies at the core of international criminal law.

Occupation. As we saw above, the only hint of protection of the rights of civilians in the Hague Conventions was in military occupations. That makes sense. When an army occupies foreign territory, IHL requires that it take over governance responsibilities in that territory. The occupier is the surrogate of the occupied state, and it assumes its obligations, except to the extent that the fighting is still going on and security requires martial measures. In a world that takes IHRL seriously, governance implies that occupation law must be constrained by human rights standards. They blend together. In occupations, human rights thinking in IHL seems natural and inevitable.

In recent decades, the two most important armed conflicts for the development of IHL have been the Israeli-Palestinian conflict and the Iraq war. Both have generated landmark legal developments, intense media coverage, and political reflection. And, of course, both involve military occupations. Unsurprisingly, they are conduits of human rights thinking into humanitarian law.

During this period, the concept of an occupation has expanded beyond what the 1907 Hague Convention Annex envisaged. According to the Annex, "Territory is considered occupied when it is actually placed under the authority of the hostile army. The occupation applies only to the territory where such authority is established, and can 
be asserted." ${ }^{42}$ Military occupation meant physical takeover. This, we might say, is the original heartland of occupation law. Under this conception, developments in occupation law would hardly carry over to in bello rules of armed conflict on the hot battlefield.

Inevitably and unsurprisingly, however, occupation law eventually expanded beyond the heartland, as lawyers argued about what actually placing territory under an army's authority means. The legal test that developed is "effective control." But in an age of long-distance technology, effective control can sometimes be exercised from afar. In Banković, the ECHR case about NATO's bombing of the Belgrade television station, the plaintiffs argued that once NATO knocked out Serbia's air defenses, it had effective control over the rights of potential civilian targets. Although the ECHR rejected the argument, it made a certain amount of sense.

This issue became especially important after the 2005 Israeli disengagement from Gaza. Even though it evacuated its settlers and troops, Israel's tight grip over the borders, air space, and sea access of Gaza left it in at least partial control of the material conditions of Gazans' daily life. Was this "effective control”? If so, Israel was occupying Gaza, with concomitant human rights obligations, notwithstanding the absence of Israeli troops. ${ }^{43}$ A parallel question arose in Iraq, when, long after the formal occupation ended, Coalition forces continued to control everyday life in many areas of the country. The question of whether Israel had effective control over Gaza led to weirdly metaphysical debates among international lawyers (is a potential reoccupation an actual occupation?

\footnotetext{
${ }^{42}$ Hague Convention II Annex, art. 42.

${ }^{43}$ For a recent discussion, see the ICC Prosecutor's report on Israel's conduct in the flotilla incident: Office of the Prosecutor, Situation on Registered Vehicles of Comoros, Greece and Cambodia, Article 53(1) Report, Nov. 6, 2014, available at http://www.icc-cpi.int/iccdocs/otp/OTP-COM-Article_53(1)-Report06Nov2014Eng.pdf, $\$ \$ 23-29$ (concluding in $\$ 27$ that "the prevalent view in the international community is that Israel remains an occupying power in Gaza despite the 2005 disengagement").
} 
etc. ${ }^{44}$ ), fittingly described by Aeyal Gross as “transcendental nonsense" - Felix Cohen’s famous label for debates conducted entirely in the Heaven of Legal Concepts. ${ }^{45}$

Some of my international law colleagues argued that these territories are no longer occupied, while others disagreed. Listening to this debate, I began to think that "occupation" should be included in the category Cohen calls "magic solving words" - words that are actually incapable of solving anything if we remain within the binary on/off framework of the traditional international law of occupation. $^{46}$

Gross proposes a functional approach, in which we unbundle the various responsibilities of an occupier to examine which of them is actually within the power of the occupier to address.

This approach is a form of human rights thinking, because Gross believes as an ethical matter that "the responsibility of an occupier is as great as its power." ${ }^{47}$ If the "occupier" can effectively exercise governance functions, and no conflicting sovereign can do so, it must - and governance functions fall within the province of human rights.

The same idea appears in Judge Giovanni Bonello's eloquent concurring opinion to the European Court's Al-Skeini decision. Al-Skeini asked whether the European Convention on Human Rights applied within the British occupation zone in Iraq, and concluded that it did. Judge Bonello ridiculed the British government's complaint that the Court was indulging in human rights imperialism: "It ill behooves a State that imposed its

\footnotetext{
${ }^{44}$ Id. at $\$ \S 24,28$.

${ }^{45}$ Aeyal Gross, Rethinking Occupation: The Functional Approach, Opinio Juris weblog, April 4, 2012; the phrase comes from Felix Cohen's classic article Transcendental Nonsense and the Functional Approach, 35 Colum. L. Rev. 809 (1935).

${ }^{46} \mathrm{Id}$.

${ }^{47}$ Id. As some might say: can implies ought.
} 
military imperialism over another sovereign State ... to resent the charge of having exported human rights imperialism to the vanquished enemy." ${ }^{48} \mathrm{He}$ added that his fondest dream would be to be regarded as a human rights imperialist. ${ }^{49}$

Judge Bonello proposes a "functional" test of jurisdiction that resembles Gross's: when a European state has "authority and control" to perform any of the enforcement functions for securing human rights in occupied territory, the jurisdiction of the European Convention includes that territory, and the state must perform the function in accordance with European human rights law. ${ }^{50}$

This is not the occasion to discuss the merits of Gross's and Bonello's legal proposals to unbundle human rights obligations and define military occupation functionally as the power to fulfill some parts of the bundle. Here, my point is to emphasize how they bring human rights thinking to bear on one special area of IHL occupation law - and then expand that area beyond its original heartland. On the surface, this represents a minor expansion of human rights thinking into IHL. Judge Bonello's proposal still pertains solely to occupation. But I want to suggest that it carries far more dramatic implications.

That is because the "functional" approach to occupation law bases human rights responsibilities on a state's power to make a practical difference to human rights within a foreign territory, during armed conflict. Under this test, it no longer matters whether we use legal labels like "occupation" or "effective control." Take these magic solving words

\footnotetext{
${ }^{48}$ Al-Skeini and Others v. United Kingdom, Application no. 55721/07, Council of Europe: European Court of Human Rights, 7 July 2011, available at: http://www.refworld.org/docid/4e2545502.html [accessed 30 September 2014], separate opinion of Judge Bonello, $\llbracket[37$.

49 "At my age, it may no longer be elegant to have dreams. But that of being branded in perpetuity a human rights imperialist, I acknowledge sounds to me particularly seductive." II39.

${ }^{50}$ Id. at TIII $10-13,16$.
} 
away and what remains? Just one thing: the basic fact of asymmetric military power in a conflict. Whenever the stronger force in a deeply asymmetric conflict can respect, protect, or fulfill the human rights of the enemy's civilians in an armed conflict, it has at least an imperfect obligation to do so, because functionally speaking it is an occupier.

This is not official legal doctrine; rather, it is moral imagination. The law of occupation becomes a moral template for interpreting IHL in all asymmetric conflicts, a template according to which the human rights of civilians play a central role. What began as the law of belligerent occupation grows into the law of asymmetric armed conflicts.

An illustration of this phenomenon is the capture-rather-than-kill controversy in the ICRC's Interpretive Guidance on Direct Participation in Hostilities. In its 2006 opinion on targeted killings, the Israeli Supreme Court required that if a targeted individual can be captured rather than killed without jeopardizing the mission or the captor's safety, he must be. ${ }^{51}$ Citing this opinion as legal authority, and appealing to the principle of avoiding unnecessary civilian harm, the ICRC proposed a capture-not-kill requirement whenever a state military goes after a civilian who directly participates in hostilities.

Some military lawyers angrily rejected the capture-not-kill requirement as an inappropriate intrusion of human rights requirements where they don't belong, which puts undue risk on soldiers. ${ }^{52}$ They argued that IHL has never prohibited killing an enemy who is not disabled and hasn't surrendered. Hayes Parks, pre-eminent among U.S. law of

\footnotetext{
${ }^{51}$ HCJ 769/02 Pub. Comm. against Torture in Israel v. Gov't of Israel [2005] IsrSC 57(6) 285, reprinted in 46 I.L.M. 375 (Isr. 2007)[henceforth, PCATI v. Israel], g[40.

${ }^{52} \mathrm{~W}$. Hayes Parks, Part IX of the ICRC "Direct Participation in Hostilities" Study: No Mandate, No Expertise, and Legally Incorrect, 42 NYU J. Int'l. L. \& Politics 769-832 (2010). The subtitle accurately conveys the rancor of the author's response to the ICRC study. To show the undue risk, the author goes into some grisly medical details about how long someone shot in the chest can continue to fight back. Id. at $810-12$.
} 
war experts, dismissed the Israeli requirement as purely domestic law with no international significance. ${ }^{53}$ That's a tendentious conclusion, because as one of the world's most active war-fighting states (and the only one whose courts review military decisions in real time), Israel's jurisprudence automatically has international significance. ${ }^{54}$ But Parks is right in one respect: the Israeli court put a great deal of weight on the fact that some of its targeted killings take place in or near occupied territory, where its human rights obligations are at a maximum. ${ }^{55}$ The ICRC generalized a doctrine growing out of occupation law to encompass all IHL. This is a perfect illustration of how the template of occupation law can export human rights thinking to IHL in all asymmetric conflicts. ${ }^{56}$

The war on terrorism. The U.S. war on terrorism, in which any geographical locale harboring al Qaeda and its (unnamed) associated forces is a potential battle space, regardless of whether the state regards itself as at peace or at war with the United States, lends special urgency to human rights thinking. As I argued soon after $9 / 11$, an unending

\footnotetext{
${ }^{53}$ Id. at $792-93$.

${ }^{54}$ Furthermore, Parks misreads the Israeli opinion. The portion he quotes says that "a civilian taking a direct part in hostilities cannot be attacked at such time as he is doing so, if a less harmful means can be employed. In our domestic law, that rule is called for by the principle of proportionality." PCATI v. Israel, II40, Parks's emphasis added. He reads the quoted language to say that only Israeli domestic law calls for the use of less harmful means. In fact, Justice Barak's opinion does not say that the requirement can be derived only from the domestic law principle and exists only within Israeli domestic law. Read in context, he first sets out an interpretation of international law and then, because that interpretation "has not yet crystalized" in "the 'gray' cases" of customary international law, he finds a domestic law source as well. ${ }^{55}$ PCATI v. Israel, $\Phi[\Phi[2,40,41,60$, which emphasize capture is especially feasible in border areas proximate to Israel, or within Israeli territory, or under the conditions of belligerent occupation.

${ }^{56}$ The ICRC study does acknowledge that capturing rather than killing most likely to be feasible in military occupations and police actions, not "classic large-scale confrontations between well-equipped and organized armed forces." But it doesn't rule out the capture-don't-kill requirement even in the latter. Nils Melzer, Interpretive Guidance on the Notion of Direct Participation in Hostilities (ICRC 2009), available at https://www.icrc.org/eng/assets/files/other/icrc-002-0990.pdf, at 80-81.
} 
armed conflict of indeterminate and potentially unlimited geographical scope threatens to depress peacetime human rights to the more limited rights protected by IHL. ${ }^{57}$

Why "more limited"? Consider that under IHL, enemy combatants can be targeted based on status alone, regardless of their level of personal involvement or actual behavior; standards of evidence and due process for killing or detaining suspected enemies are relaxed far below those of peacetime civilian life; civilians and their property can lawfully be exposed to higher risk of collateral damage than peacetime life would ever tolerate. ${ }^{58}$ Faced with the prospect of long-term displacement of human rights to the lower level of wartime protections, it seems quite proper to push back by trying to inject human rights thinking into the laws of war. Otherwise, the entire project of international human rights is as good as gone - placed in perpetual derogation by an endless war on terrorism. Once the U.S. government declares that in principle all the world could be a battlefield, then the demand for human rights even on the battlefield becomes entirely justifiable.

\section{Overextending human rights thinking}

It is entirely possible for human rights advocates to push back too hard and too far - to deny that armed conflict is different, in fact decisively different, from peacetime. The most common form of this denial is insisting that contemporary state conflicts with terrorist groups are always law enforcement matters governed by human rights standards of due process in targeting, arresting, detaining, and trying terrorism suspects. I agree that

\footnotetext{
${ }^{57}$ David Luban, The War on Terrorism and the End of Human Rights, 22 Phil. \& Pub. Pol'y Q. 9 ( Summer 2002), available at http://scholarship.law.georgetown.edu/facpub/892. Reprinted in multiple sources, most recently as Chapter 1 of Torture, Power, and Law.

${ }^{58}$ See Jonathan Thompson Horowitz's chapter in this volume, which compares LOAC principles of proportionality and necessity with their peacetime counterparts, as exemplified in the United Nations Code of Conduct for Law Enforcement Officials and the United Nations Basic Principles on the Use of Force and Firearms by Law Enforcement Principles, showing how the latter are significantly more stringent.
} 
sometimes insisting on law enforcement standards is absolutely right. For example, when the U.S. government arrested suspected terrorist Jose Padilla in 2002, it declared him an enemy combatant in the armed conflict with al Qaeda. ${ }^{59}$ This allowed the government to hold Padilla as a military prisoner for years, and he was not charged with any crime until 2005. But Padilla was arrested by civilian law enforcement in Chicago, not captured by the military on the battlefield. He was and is a U.S. citizen with the full panoply of constitutional rights. The only basis for finding that Padilla was an enemy combatant was an affidavit by a civilian official in Washington, with no supporting evidence. Instead of offering evidence, the government asserted that U.S. courts must defer to the commander in chief in "military" matters (the reason for the scare-quotes should be obvious). The judge pointed out that he was fully competent to evaluate evidence about Padilla's legal status, and indeed that this is the heart of a court's institutional competence. But he concluded that he must defer to the commander in chief. ${ }^{60}$

Padilla's capture and imprisonment were factually indistinguishable in every way from a criminal arrest. The sole reason the government classified him as a wartime captive was to interrogate him without a lawyer, or indeed any human contact - and to expand the president's power as commander in chief. This was outrageous. ${ }^{61}$ It is obvious that civilian law enforcement standards should have protected Padilla, and that the government grossly abused its power in order to advance the frightening proposition that the president has near-absolute authority to strip legal protections away from whomever the president wants, simply by declaring the person an enemy combatant.

\footnotetext{
${ }^{59}$ Padilla v. Bush, 233 F. Supp. 2d 564, 606-08 (S.D.N.Y. 2002)

${ }^{60}$ Id. at 607-08.

${ }^{61}$ So I've argued at length, in David Luban, On the Commander-in-Chief Power, 81 S. Cal. L. Rev. 477 (2008).
} 
But in other cases, denying the existence of an armed conflict and insisting on peacetime due process standards flies in the face of reality. Human rights groups have reflexively described drone strikes as extrajudicial assassinations without due process of law. ${ }^{62}$ They can be under some circumstances. But they needn't be. A drone is nothing more than a platform for long-distance weapons delivery, no different in principle from a bomber or for that matter a cannon. It is clearly permissible to use long-distance weapons in an armed conflict. Indeed, in an armed conflict a targeted killing is not only different from an illegal assassination, it is the only legally permitted form of killing: the opposite of a targeted attack is an untargeted and therefore indiscriminate attack. The argument that low-level conflicts with terrorist groups can never, as a matter of human rights principle, count as armed conflicts, only as law enforcement problems, seems dogmatic and wrong in a world where law enforcement against terrorists is spotty and often nonexistent or even impossible. ${ }^{63}$ The argument overextends the proper reach of human rights thinking, declaring that the rule of law prevails everywhere - presumably, in the hope that declaring it so will make it so.

Another overextension of human rights thinking arises in some of the revisionist just war theory that occupies a prominent place in contemporary philosophical discussions of war. Some revisionists operate from within a framework set by three

\footnotetext{
${ }^{62}$ E.g., Report of the Special Rapporteur, Asma Jahangir, U.N. Doc. E/CN.4/2003/3 (Jan. 13, 2003), §39, describing a 2002 U.S. drone strike in Yemen on an al Qaeda planner that also killed five passengers in his car as "a clear case of extrajudicial killing." Subsequent UN Special Rapporteurs have been more circumspect about whether or not drone strikes are properly described as extrajudicial killings.

${ }^{63}$ The qualification "low-level" is important, because no human rights group denies that open battle with terrorist groups is armed conflict. Open battle meets the legal criteria of duration, intensity, and organization that the ICRC uses to define armed conflict. How is the Term "Armed Conflict" Defined in International Humanitarian Law?, ICRC Opinion Paper (March 2008).
} 
premises. ${ }^{64}$ First, the human rights against killing and other aggravated violence are of fundamental moral importance. Second, individuals lose those rights only by their own conduct that menaces the basic rights of other people - paradigmatically, violently assaulting the innocent or causing others to do so. Third, the conditions under which individuals lose those rights are the narrow conditions for self- and other-defense in domestic society. (The third premise is not always obvious in revisionist theory, but it is implicit in the characteristic and striking way that revisionists argue from moral intuitions about self-defense in hypothetical situations of one-on-one murderous assault.) From these premises, important and controversial conclusions follow. To cite just one example: the conditions of targetability under a theory of individual self-defense do not map comfortably onto IHL's status-based distinction between combatants and non-combatants, so revisionism may reject both sides of the principle of distinction: civilian immunity and military targetability.

The first premise of revisionism - the central role of human rights against violence - is unproblematic. No form of human rights thinking could reject it; I am tempted to say that no respectable moral code could reject it, even if the code does not use the vocabulary of human rights. The other two premises, however, lean too heavily on the conditions of peacetime society; as Michael Walzer pointedly quipped, revisionist theory is a perfect ethics of warfare if war were a peacetime activity. ${ }^{65}$

Human rights thinking simply cannot will away the dramatic differences between war and peace. The peacetime use of lethal violence in self-defense can be narrowly

\footnotetext{
${ }^{64}$ I am thinking particularly of path-breaking work such as Jeff McMahan's Killing in War and David Rodin's War and Self-Defense, as well as their numerous papers. I don't mean, however, that they explicitly set out and endorse the premises I am attributing to them here.

${ }^{65}$ Walzer, Response to McMahan's Paper, 34 Philosophia.43 (2006).
} 
constrained because in domestic society the need for self-help is an exception. Leviathan is a few blocks away in a police cruiser, and even on mean streets, most of the time you can flee or dial 911, rather than pulling out a gun and blazing away. In peacetime society, trigger-happy defenders can be more dangerous than murderers; hence the narrow conditions of personal self-defense in domestic law. That's a poor model of self-defense in wartime.

As for the wartime use of lethal violence, it cannot always be narrowly focused on all and only those individuals who actually pose a threat, because in the fog of war we seldom know which is which. Individual liability is far too granular a criterion for violence in armed conflict, where action is at a distance and armed enemies operate in groups. The domestic analogy of war to peacetime conflict risks losing sight of the terrifying disanalogies, and I think revisionists would do well to abandon their domestic hypotheticals and show a bit more skepticism about moral intuitions honed in peacetime society.

\section{Human rights thinking and the civilian point of view}

What, then, is the proper place for human rights thinking in armed conflict? We have seen it several times in the course of this argument: it consists in a heightened solicitude toward the civilians caught in a battle space whose basic rights are affected by the war.

This heightened solicitude can manifest itself in many specific ways. As someone who has written about various aspects of just war from the standpoint of human rights thinking, I will risk self-indulgence and draw from my own work to illustrate. I don't mean to suggest that the positions on the issues that follow are the only ones that human 
rights thinking permits, or even that they harmonize perfectly with human rights thinking. They don't. They merely represent one line of thought that brings human rights thinking to bear on the theory of just war and IHL.

Jus ad bellum. Start with Kofi Annan's famous address to the General Assembly in 1999:

State sovereignty, in its most basic sense, is being redefined by the forces of globalization and international cooperation. The State is now widely understood to be the servant of its people, and not vice versa. At the same time, individual sovereignty - and by this I mean the human rights and fundamental freedoms of each and every individual as enshrined in our Charter - has been enhanced by a renewed consciousness of the right of every individual to control his or her own destiny. ${ }^{66}$

On Annan's conception, state sovereignty exists to protect the human rights of the state's people, not (as in the classic Island of Palmas doctrine) to protect foreigners' interests within the state, and certainly not to protect a massive human rights violator from outside intervention. Sovereignty loses its normative force when the state violates basic human rights. ${ }^{67}$ In that case, we should reinterpret just cause of war in terms of defending people's basic rights rather than defending states' sovereignty. The article 2(4)-article 51 framework of the UN Charter must accordingly be reinterpreted. In 1980, I argued that the formula should be this:

\footnotetext{
${ }^{66}$ Secretary-General Presents His Annual Report to General Assembly, UN Press Release SG/SM7136, GA 9596 (Sept. 20, 1999), available at http://www.un.org/News/Press/docs/1999/19990920.sgsm7136.html.

${ }^{67}$ The term "basic rights" can be understood intuitively as the most fundamental human rights; but I prefer Shue's definition of basic rights as those human rights (like the right to physical security against violence and to minimum subsistence) the fulfillment of which is necessary to enjoying any other human rights.
} 
(1) A just war is a war in defense of basic human rights, or (alternatively) a war of self-defense against an unjust war.

(2) An unjust war, on the other hand, is a war subversive of human rights that is not a war in defense of basic human rights. ${ }^{68}$

Clause (1) brings human rights thinking to Article 51 self-defense, while clause (2) brings human rights thinking to the concept of aggression.

Notice that on this reconceptualization of just cause, humanitarian military interventions to stop widespread violations of human rights can be justifiable - and not only when the human rights violations are core international crimes, as under the Responsibility to Protect doctrine, but also in cases where other basic rights are threatened, such as famines where only outside military forces are capable of rescuing the endangered population. ${ }^{69}$ It likewise follows from human rights thinking that punishing an enemy's bad behavior through military violence cannot constitute just cause of war, because using violence against an adversary state inevitably amounts to collective punishment of its civilians. ${ }^{70}$

Risk. On the other hand, preventive war necessary to forestall a massive attack on basic rights can, under some circumstances, be morally permissible under human rights thinking, provided of course that it satisfies ad bellum proportionality as well as other

\footnotetext{
${ }^{68}$ David Luban, Just War and Human Rights, 9 Phil. \& Public Affairs 160 (1980), corrected and reprinted in International Ethics: A Philosophy \& Public Affairs Reader (Charles Beitz et al. eds., 1985).

${ }^{69}$ See Margaret M. DeGuzman, When Are International Crimes a Just Cause of War?, Va. J. Int'1. L. (forthcoming)(arguing that it is a mistake to link the R2P doctrine to international crimes, and that R2P can rightly be expanded to cover other situations that jeopardize a population). I discuss the permissibility conditions of humanitarian intervention in David Luban, Intervention and Civilization: Some Unhappy Lessons of the Kosovo War, in Global Justice and Transnational Politics: Essays on the Moral and Political Challenges of Globalization 79 (Pablo de Greiff \& Ciaran Cronin, eds., 2002).

${ }^{70}$ David Luban, War as Punishment, 39 Phil. \& Public Affairs 299 (2011).
} 
relevant criteria. ${ }^{71}$ It can readily be subsumed under Shue's conception of a social guarantee that a state provides against a standard threat to the basic rights of its inhabitants - in other words, the "protect" part of human rights under the "respect, protect, fulfill" model. Recall that under Shue's thick conception of human rights obligations, it is not enough for a state to protect its citizens from ongoing attacks on their basic rights. It is also supposed to guarantee its inhabitants' rights against standard threats, and an armed attack under preparation by an enemy is a standard threat. It follows that human rights thinking about war encompasses risk management as well as ongoing military defense. It may sound counter-intuitive that human rights thinking could countenance preventive war rather than forbidding it, but the phrase "anticipatory self-defense" is not simply a newspeak name for aggression (notwithstanding its abuse by the United States in Iraq), and it is an aspect of the defense of basic rights.

One might object that by weighing the magnitude of a nascent attack on basic rights against the magnitude of an armed preventive response, the preventive war argument departs from human rights thinking by aggregating rather than individuating rights infringements. According to this objection, genuinely human rights-based thinking would focus instead on the fact that a preventive war will inevitably damage innocent civilians in violation of their own basic rights. Because the war is preventive, neither they nor their state has actually done anything yet that would justify an attack on their rights. ${ }^{72}$

\footnotetext{
${ }^{71}$ The circumstances, I have argued, are tailored narrowly to an adversary whose ideology and past history of violence, combined with current hostile intentions and weapons programs, make it likely that it plans to launch an attack when it acquires the capacity. Furthermore, it has to be an attack with a weapon one use of which is likely to cause mass casualties. David Luban, Preventive War, 32 Phil. \& Public Affairs 207, 22932 (2004); Preventive War and Human Rights, in Preemption: Military Action and Moral Justification 171(Henry Shue \& David Rodin, eds., 2007).

${ }^{72}$ See, e.g., David Rodin, The Problem with Prevention, in Shue \& Rodin, supra note 69.
} 
Without offering a detailed reply to this objection (which I have done elsewhere ${ }^{73}$ ), I want to acknowledge something importantly correct in it. In wartime, human rights will be violated on all sides, and comparing the violations by aggregating them is a "utilitarianism of rights," which some philosophers reject as a mistake about the very nature of rights. ${ }^{74}$ These objectors find something fundamentally inconsistent between body-counts and the commitment to individual human dignity. ${ }^{75}$ This is not a trivial or mistaken concern, but I think the utilitarianism of rights is inescapable in human rights thinking about war. It is still human rights thinking because the weighing and trade-offs take place between rights and rights: basic rights cannot be traded off for interests less significant than basic rights. To be sure, allowing a right to be traded off for anything, even another right, offends against the entitlement commitment inherent in human rights thinking. But when entitlements conflict with each other, something has to give, and human rights thinking cannot ignore conflicts among rights or argue them away. $^{76}$

The argument about preventive war adds an additional wrinkle to the aggregation of rights: it allows states to take military action against massive threats to its inhabitants' basic rights that are not sure things but only highly probable, in the strong sense that not only is the likelihood very high, but one thing that makes it high is the adversary's

\footnotetext{
${ }^{73}$ Luban, Preventive War and Human Rights, supra note 65.

${ }^{74}$ Robert Nozick coined the term; see Anarchy, State, and Utopia 28-30 (1973); he contrasts it unfavorably with the view of rights as side-constraints on action, under which minimizing rights violations cannot be a goal of action.

${ }^{75}$ The classic statement of this view is John M. Taurek, Should the Numbers Count?, 6 Phil. \& Public Affairs 293 (1977). Taurek's answer to his title question is a resounding no, and he believes that if you have a choice between saving one life and saving five, you should flip a coin, because that gives each of the six an equal chance of surviving. Id. at 303. Several philosophers, including Francies Kamm, Gregory Kavka, Rahul Kumar, and T. M. Scanlon have responded with nonconsequentialist arguments that the numbers count. For a survey essay showing that those responses confront knotty problems, see David T. Wasserman \& Alan Strudler, Can a Nonconsequentialist Count Lives?, 31 Phil. \& Public Affairs 71 (2003). ${ }^{76}$ On this point, see Griffin, supra note 3, chapter 3.
} 
belligerent intentions, demonstrated through ongoing action, past track record, and ideology. Not just any remote threat to basic rights is a just cause for preventive war, only one that crosses a high risk threshold because the adversary is deliberately pushing toward the brink. My claim here is that warding off high-likelihood massive threats to rights, even though they are not certain, is required by the "protect" obligation in the "respect, protect, fulfill" trio.

Jus ex bello. Parallel reasoning about risk to basic human rights can be used to address the question of jus ex bello, the morality of when one must terminate a just war. Can states keep fighting a just war until they have so decisively beaten their adversary that the risk the adversary poses to basic rights is effectively reduced to zero? To say yes means that the state can keep pounding away until the adversary's military capability is not merely defeated but completely pulverized. Cast in the language of risk, that means the state could continue to transfer risks from its own population to the population of the enemy even when its marginal gains in safety are slight and the marginal damage to the enemy's population are large. This, under human rights thinking, is immoral. The world is an intrinsically risky place, with an irreducible "cosmic background radiation" of risks to basic rights posed by enemies. States are never justified in continuing a war that shifts risks onto others once they have reduced their own to the background level. ${ }^{77}$

This matters enormously in the so-called war on terror. Recall that President George W. Bush proclaimed that the war "will not end until every terrorist group of global reach has been found, stopped and defeated." ${ }^{78}$ As recently as 2013, the

\footnotetext{
${ }^{77}$ So Gabriella Blum and I argue in Unsatisfying Wars: Degrees of Risk and the Jus ex Bello, Ethics (forthcoming).

78 "Transcript of President Bush's address," 20 September 2001. Available at http://georgewbushwhitehouse.archives.gov/news/releases/2001/09/20010920-8.html.
} 
Washington Post editorialized that "like all wars, this one will end only if one party is defeated or both agree to lay down their weapons."79 President Bush and the Post editorialist voice the demand for zero risk, even as the U.S. campaign continues to impose grave risks on others. Under human rights thinking, such an approach to the jus ex bello is unacceptable.

Jus in bello. These ad bellum and ex bello questions of basic human rights and risk transfer have in bello counterparts. One much-discussed issue is whether a state's soldiers must take on additional risk to themselves in order to minimize civilian casualties among the enemy's civilians. IHL gives no clear answer. It requires fighters to take "constant care" to reduce civilian casualties, and to do everything "feasible" to that end, but there is no agreement about how much risk-taking on the part of soldiers is feasible, nor what "constant care" means in practice. In a well-known article, Asa Kasher and Amos Yadlin argued that although state soldiers must place the protection of their own civilians above their own protection, they can place self-protection above the protection of the enemy's civilians. ${ }^{80}$ Avishai Margalit and Michael Walzer responded that a civilian is a civilian regardless of nationality, and soldiers must take exactly the same risks on behalf of enemy non-combatants as they would if the civilians were their own people. ${ }^{81}$

There are really two issues here, one about the relative worth of soldiers and civilians, the other about "our" civilians versus "theirs." I believe that human rights

\footnotetext{
${ }^{79}$ Washington Post Editorial Board, "Wishful Thinking in the War on Terror," Wash. Post, Aug. 5, 2013, available at http://www.washingtonpost.com/opinions/wishful-thinking-on-the-war-onterror/2013/08/05/3485e982-fde3-11e2-9711-3708310f6f4d_story.html.

${ }^{80}$ Asa Kasher and Amos Yadlin, Assassination and Preventive Killing, 25 SAIS Review 41, 49-51 (WinterSpring 2005).

${ }^{81}$ Avishai Margalit and Michael Walzer, Israel: Civilians and Combatants, New York Review of Books, May 14, 2009; Asa Kasher and Major General Amos Yadlin, with a reply by Margalit and Walzer, Israel \& the Rules of War: An Exchange, New York Review of Books, June 11, 2009.
} 
thinking gives a clear answer: all lives, soldiers' lives and civilians', our civilians and theirs, have the same worth. ${ }^{82}$ Therefore soldiers must take on the same minimum levels of risk to spare "enemy" civilians as they would to spare their own civilians. (Of course, they can choose take additional heroic risks, and it would not be wrong to do so selectively on behalf of their own civilians.)

Does this argument also mean that soldiers can transfer risks to civilians at a oneto-one exchange rate? If all else were equal, human rights thinking answers yes: the individual-worth commitment is egalitarian. The complication is that all else is not equal, because in many cases the soldiers are the ones creating the risk to civilians, and common sense morality suggests that the larger burden of risk falls on risk-causers than innocent bystanders. In the words of the old tort chestnut Rylands v. Fletcher, "When one person, in managing his own affairs, causes, however innocently, damage to another, it is obviously only just that he should be the party to suffer." ${ }^{83}$ Here, as in other instances of human rights thinking, examining the problem from the standpoint of the innocent civilian helps us disentangle a knotty problem. Although the morality of war cannot ask soldiers to take suicidal risks to save civilians, their vocation requires them to take on some additional risk to spare the basic rights of civilians, because the soldiers are the ones whose attacks create the risk to civilians.

Military necessity. As a final example, I believe that human rights thinking requires us to reconceptualize the concept of military necessity. Military necessity has always been the counter-argument to the claims of humanitarianism, and until very

82 David Luban, Risk Taking and Force Protection, in Reading Walzer 277 (Itzhak Benbaji \& Naomi Sussman, eds., 2014). For another example of human rights thinking about this issue, see Eyal Benvenisti, Human Dignity in Combat: The Duty to Spare Enemy Civilians, 39 Isr. L. Rev. 81 (2006).

${ }^{83}$ Rylands v. Fletcher, L.R. 3 H.L. 330 (1868)(Cranswell, L.). 
recently it was a decisive counter-argument: Kriegsraison trumps Kriegsmanier, as the Prussian military maxim would have it. The Lieber Code of 1863 was the first explicit statement that military necessity cannot justify war crimes; even so, historian John Fabian Witt argues that the Code contains so many inconsistencies on this point that Lieber could not have really meant it. ${ }^{84}$ Only in the post-World War II Hostages case did anything like settled law emerge that prohibits war crimes even in cases of military necessity.

However, the Hostages formula remains distinctly forgiving to militaries under the guise of necessity:

Military necessity permits a belligerent, subject to the laws of war, to apply any amount and kind of force to compel the complete submission of the enemy with the least possible expenditure of time, life, and money. ${ }^{85}$

So, provided that a military force avoids overt LOAC violations, it can describe all advantageous actions as military necessities, regardless of how much suffering they inflict on civilians and how trivial the advantage. Furthermore, this expansive conception of military necessity comes close to eviscerating the LOAC requirement to take all "feasible" precautions to protect innocent civilians: the military necessity of not taking a precaution makes it infeasible. From the standpoint of human rights thinking, these consequences are intolerable. Human rights thinking demands a different conception of necessity, according to military advantage must be weighed against civilian damage. If the marginal military advantage is slight, but the marginal civilian damage is not, the

\footnotetext{
${ }^{84}$ Lieber Code, art. 14. See generally John Fabian Witt, Lincoln's Code, chapter 8, and Witt, A Response to David Luban, JustSecurity weblog, Oct. 3, 2013, available at http://justsecurity.org/1615/witt-responsedavid-luban/.

${ }^{85}$ US v. List (American Military Tribunal, Nuremberg, 1948), 11 NMT 1230, at 1253.
} 
claim of military necessity must be rejected. ${ }^{86}$ In other words, the concept of military necessity contains a proportionality requirement within it that requires taking civilian harm into account.

The important difference between this marginal conception of necessity and the Hostages formula is that the latter simply ignores the rights of civilians, where the marginal conception demands that necessity assessments take full account of them.

No doubt objections could be raised against all the arguments and conclusions I have canvassed here. My aim here is not to defend them, but to propose them as examples of the kind of human rights thinking that rightfully belongs in IHL - human rights thinking that does not downplay the difference between war and peace, but that insists on the basic human rights of civilians as well as warriors as the moral heart of just war theory properly conceived - in the language of Furundzija with which I began this essay, "the essence of the whole corpus of international humanitarian law as well as human rights law."

\footnotetext{
${ }^{86}$ David Luban, Military Necessity and the Cultures of Military Law, 26 Leiden J. Int'1. L. 315 (2013), 34147.
} 